\title{
Methodological Approach for Modeling of Multienzyme in-pot Processes
}

Andrade Santacoloma, Paloma de Gracia; Roman Martinez, Alicia; Sin, Gürkan; Gernaey, Krist; Woodley, John

Publication date:

2011

Document Version

Publisher's PDF, also known as Version of record

Link back to DTU Orbit

Citation (APA):

Andrade Santacoloma, P. D. G., Roman Martinez, A., Sin, G., Gernaey, K., \& Woodley, J. (2011).

Methodological Approach for Modeling of Multienzyme in-pot Processes. Abstract from 21 st European Symposium on Computer Aided Process Engineering, Chalkidiki, Greece.

\section{General rights}

Copyright and moral rights for the publications made accessible in the public portal are retained by the authors and/or other copyright owners and it is a condition of accessing publications that users recognise and abide by the legal requirements associated with these rights.

- Users may download and print one copy of any publication from the public portal for the purpose of private study or research.

- You may not further distribute the material or use it for any profit-making activity or commercial gain

- You may freely distribute the URL identifying the publication in the public portal 


\title{
Methodological approach for modeling of multi-enzyme in-pot processes
}

\author{
Paloma A. Santacoloma ${ }^{a}$, Alicia Roman-Martinez ${ }^{b}$, Gürkan Sin $^{b}$, Krist V. Gernaey ${ }^{a}$, and John M. \\ Woodley ${ }^{2}$ \\ ${ }^{a}$ PROCESS, ${ }^{b}$ CAPEC, Department of Chemical and Biochemical Engineering, Technical University of \\ Denmark, Søltofts Plads, Building 229, 2800-Kgs. Lyngby, Denmark
}

Multi-enzyme catalyzed processes are now considered in many cases as an innovative method to assist in the synthesis of complex compounds of industrial interest [1]. These processes are particularly interesting from a scientific perspective when considered for operation as a mixture of enzymes (catalyzing several reactions) in a single pot [2], so called multi-enzyme 'in-pot' processes. Furthermore, multi-enzyme 'in-pot' processes can be considered as an application of process intensification, since separation and purification steps of intermediate products may be eliminated [3]. Consequently, it potentially leads to considerable process improvements like increases in the process yield and reduction in downstream processing and operating costs.

Mathematical modeling plays an important role for developing this multi-enzyme in-pot approach, integrated with a computer-aided framework [4]. The framework mainly provides a systematic method to build high quality models in an efficient manner. The idea is to use the models to find either promising configurations for experimental validation, or, evaluate and analyze an existing process under different conditions by simulation, to identify opportunities for improvement.

The important pharmaceutical intermediate $\mathrm{N}$-acetyl-D-neuraminic acid (Neu5Ac) is produced due to its anti-viral, anti-cancer and anti-inflammatory effects [5]. One innovative option for producing this compound is by combining two enzymes in a single reactor [3]. This bi-enzyme in-pot process consists of two cascade reactions, as shown in Figure 1, where the first enzyme (epimerase, E.C. 5.1.3.8) uses $\mathrm{N}$-acetyl-D-glucosamine (GlcNAc) as a substrate to be transformed to $\mathrm{N}$-acetyl-D-manosamine (ManNAc) which is, at the same time, used as a substrate for the second enzyme (aldolase, E.C. 4.1.3.3) in combination with pyruvic acid to yield the desired product (Neu5Ac).

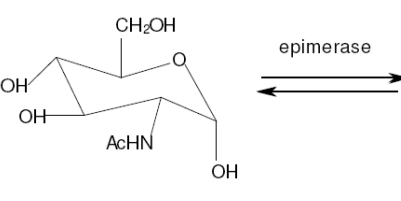

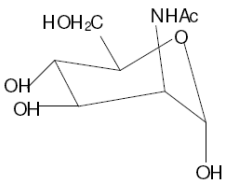

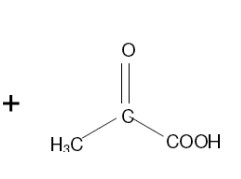

C

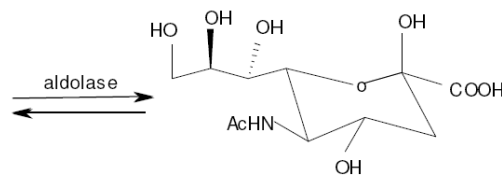

D

Figure 1. Synthesis of Neu5Ac from GlcNAc in two cascade reactions; $\boldsymbol{A}$ : N-acetyl-D-glucosamine (GlcNAc); B: N-acetyl-D-manosamine (ManNAc); C: pyruvic acid (Pyr); $\boldsymbol{D}:$ N-acetylneuraminic acid (Neu5Ac); Enzymes: Nacylglucosamine-2-epimerase, $\mathrm{N}$-acetylneuraminic acid aldolase

The objective of this contribution is to show the methodological approach that enables a systematic modeling of multi-enzyme in-pot processes. This methodology is exemplified through the Neu5Ac case study.

\section{References}

1. D.Y. Murzin and R. Leino, ChERD, 2008, 86, 1002

2. A. Bruggink, R. Schoevaart and T. Kieboom, Org Proc Res Dev, 2003, 4, 622

3. P. Lutze, A. Román-Martinez, J. M. Woodley and R. Gani, European Symposium on Computer Aided Process Engineering - proceeding, 2010, 20 ${ }^{\text {th }}, 241-246$

4. R. Morale-Rodriguez and R. Gani, Computer Aided Chemical Engineering, 2007, 24, 207

5. V. Zimmermann, H. Hennemann, T. Daußmann and U. Kragl, Applied Microbial Biotechnology, 2007, 76, 597-605. 